\title{
Knowledge of sex workers about HIV/AIDS and its influence on sexual practices
}

\author{
Conhecimento de profissionais do sexo sobre HIV/Aids e influência nas práticas sexuais \\ Conocimiento de los profesionales del sexo sobre el VIH/SIDA y su influencia en las prácticas sexuales
}

\section{Anna Cláudia Freire de Araújo Patrício' ORCID: 0000-0002-9310-4700}

Valéria Peixoto Bezerra"

ORCID: 0000-0002-5226-6789

Jordana Almeida Nogueira"

ORCID: 0000-0002-2673-0285

Maria Adelaide Silva Paredes Moreira" ORCID: 0000-0001-9460-9172

Brígido Vizeu Camargo"' ORCID: 0000-0002-9529-4923

Jiovana de Souza Santos'v ORCID: 0000-0001-6056-8800

Universidade Federal de Uberlândia. Uberlândia, Minas Gerais, Brazil.

"Universidade Federal da Paraíba. João Pessoa, Paraíba, Brazil.

"'Universidade Federal de Santa Catarina, Brazil.

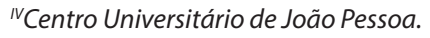
João Pessoa, Paraíba, Brazil.

How to cite this article: Patrício ACFA, Bezerra VP, Nogueira JA, Moreira MASP, Camargo BV, Santos JS. Knowledge of sex workers about HIV/AIDS and its influence on sexual practices. Rev Bras Enferm. 2019;72(5):1311-7. doi: http://dx.doi.org/10.1590/0034-7167-2018-0590

Corresponding Author:

Anna Cláudia Freire de Araújo Patrício E-mail: claudia.freirearaujo@gmail.com

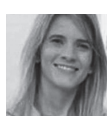

Submission: 07-22-2018 Approval: 11-23-2018

\begin{abstract}
Objective: assess the knowledge of sex workers about HIV/AIDS and its influence on sexual practices. Method: Ninety women participated in the study. The Scientific Knowledge Test about HIV/AIDS and sexual practices was used. The Wald test was applied to verify the relationship between knowledge and sexual practices with statistical significance of $p<0.05$. Results: the score of $61.7 \%$ of correct answers in all three dimensions stands out; $72.2 \%$ have sexual intercourse without a condom in exchange for a large amount of money; $53.3 \%$ have sex during the menstrual period; $62.2 \%$ have sexual intercourse with drug users; $75.6 \%$ have sex with clients showing lesions on the penis or anus. The B coefficient $(-0.19)$ showed that the higher the knowledge about HIV/AIDS, the lower the practice of risky sexual behaviors. Conclusion: the influence of knowledge about HIV/AIDS on sexual practices was not statistically significant, but the sexual practices and insufficient knowledge about prevention, physiological and behavioral attributes were observed.

Descriptors: HIV; Sex Workers; Knowledge; Sexual Behavior; Community Health Nursing.
\end{abstract}

\section{RESUMO}

Objetivo: avaliar o conhecimento de profissionais do sexo sobre HIV/Aids e sua influência nas práticas sexuais. Método: Participaram 90 mulheres. Utilizou-se o Teste de Conhecimento Científico sobre o HIV/Aids e práticas sexuais. Aplicou-se teste Wald para verificar a relação entre conhecimento e práticas sexuais com $p<0,05$ estatisticamente significativo. Resultados: destacam-se o escore de $61,7 \%$ de acertos de respostas nas três dimensões; $72,2 \%$ praticam sexo sem preservativo em troca de quantia financeira maior; $53,3 \%$ praticam sexo em período menstrual; $62,2 \%$ possuem relação sexual com usuário de drogas; $75,6 \%$ com cliente apresentando feridas no pênis ou ânus. O coeficiente $B(-0,19)$ revelou que quanto maior o conhecimento sobre HIV/Aids, menor a adoção de práticas sexuais de risco. Conclusão: a influência do conhecimento sobre HIV/Aids nas práticas sexuais não se apresentou estatisticamente significativa, porém observou-se a realização de práticas sexuais de risco e conhecimento insuficiente quanto a prevenção, atributos fisiológicos e comportamentais. Descritores:HIV; Profissionais do Sexo; Conhecimento; Comportamento Sexual; Enfermagem em Saúde Comunitária.

\section{RESUMEN}

Objetivo: evaluar el conocimiento de los profesionales del sexo sobre el VIH/SIDA y su influencia en las prácticas sexuales. Método: Participaron 90 mujeres. Se utilizó la Prueba de Conocimiento Científico sobre el VIH/SIDA y las prácticas sexuales. Se aplicó el test Wald para comprobar la relación entre el conocimiento y las prácticas sexuales con $\mathrm{p}<0,05$ estadísticamente significativo. Resultados: se destacan el puntaje de un $61,7 \%$ en aciertos en las respuestas de las tres dimensiones; Un $72,2 \%$ practican sexo $\sin$ preservativo a cambio de una suma financiera mayor; Un 53,3\% practican sexo durante el período menstrual; Un 62,2\% tiene relación sexual con usuario de drogas; y un $75,6 \%$ con clientes que estaban presentando heridas en el pene o ano. El coeficiente $B(-0,19)$ reveló que cuanto más se tiene conocimiento sobre el VIH/SIDA, menos es la adopción de prácticas sexuales arriesgadas. Conclusión: no se comprobó la relación estadísticamente significativa de la influencia del conocimiento sobre el VIH/SIDA en las prácticas sexuales, pero se observó la adopción de prácticas sexuales arriesgadas y conocimiento insuficiente en cuanto a la prevención, así como los atributos fisiológicos y comportamentales. Descriptores: VIH; Trabajadores Sexuales; Conocimiento; Conducta Sexual; Enfermería en Salud Comunitaria. 
Knowledge of sex workers about HIV/AIDS and its influence on sexual practices Patrício ACFA, Bezerra VP, Nogueira JA, Moreira MASP, Camargo BV, Santos JS.

\section{INTRODUCTION}

The growth in the number of cases of infection by the Human Immunodeficiency Virus (HIV) in Brazil is characterized by multiple dimensions and differences in the epidemiological profile throughout the regions of the country, with significant stabilization trend of the number of cases with an average of 20.7 per 100 thousand inhabitants ${ }^{(1)}$.

In Brazil, the Health Information System reported 136,945 cases of HIV (2007-2016), being the Northeast region responsible for recording 6,435 cases of infection, 44,766 in women. The most prevalent age group (52.3\%) was between 20 and 34 years ${ }^{(1)}$.

Study conducted by the Department of Sexually Transmitted Infections, AIDS and Viral Hepatitis in ten Brazilian cities in 2009, with 2,523 female sex workers (FSWs), recorded 4.9\% (124) cases of AIDS in this group ${ }^{(2)}$. These women are considered vulnerable to sexually transmitted Infections (STIs), due to risky behavior, such as the use of licit and illicit drugs, sexual intercourse without condoms, difficult health services accessibility, enhanced by social exclusion ${ }^{(3)}$.

Monitoring of the practices and behavior of populations more vulnerable to HIV infection is essential for effective interventions in these subgroups, generating significant changes in the transmission pattern of HIV/AIDS in the general population ${ }^{(4)}$.

Knowledge about HIV transmission routes was observed in a study with 395 female sex workers, in which the majority of the interviewees considered that a healthy-looking person can be infected with HIV (91.7\%) and that needle and syringe sharing during intravenous drug use can transmit the viral agent (99.0\%). However, there are erroneous information about transmission through mosquitoes and the ignorance of transmission through breastfeeding ${ }^{(5)}$.

Study ${ }^{(6)}$ conducted with female sex workers showed benefits in the implementation of educational activities to minimize the vulnerability to HIV infection, demonstrating the value of knowledge about preventive practices.

Female sex workers know about the importance of having safe sex, but they are influenced by the desire of their sexual partners and by the lack of negotiating power for condom use. Other factors may lead these women to have unprotected sex, such as better remuneration, emotional involvement, confidence in the partner and the effect caused by the use of alcohol or drugs ${ }^{(7-9)}$.

Sex workers and their clients often have anal sex, but a relatively high proportion of customers insist on not using condoms, generating greater risk of contracting HIV and transmitting it to other sexual partners, either men or women. It is important to consider the need for safe anal sex and incorporate this theme into prevention programs ${ }^{(10)}$.

Condom use with clients is directly proportional to the use of illicit drugs, alcohol, as well as to the level of knowledge of female sex workers about the modes of transmission of STIs and HIV ${ }^{(11)}$.

Knowing that unprotected sex favors HIV transmission and that female sex workers use sex as a source of livelihood, it is essential to investigate women's knowledge about HIV/AIDS and identify the influence of this knowledge on sexual practices, aiming to minimize HIV contagion in this social group.

\section{OBJECTIVE}

Assess the knowledge of female sex workers about HIV/AIDS and its influence on sexual practices.

\section{METHOD}

\section{Ethical aspects}

The study complied with the ethical principles set out in Resolution No. 466/2012 of the National Health Council and received a favorable opinion from the Research Ethics Committee at the Federal University of Paraiba.

\section{Design, location and period}

Exploratory and quantitative research conducted at the Prostitutes Association of Paraíba (APROS/PB), in João Pessoa-PB/ Brazil. Data were collected between May and September 2014.

\section{Population and sample: inclusion and exclusion criteria}

APROS/PB records 160 women of various age groups and backgrounds from the Brazilian state of Paraíba. We considered the population base of 92 female sex workers recorded in APROS/PB in 2013 to conduct the study, obeying the inclusion criteria: exercise professional activity in João Pessoa-PB and be between 18 to 30 years.

Two sex workers refused to participate in the study. This age group was chosen for comprising a population group with a high prevalence of HIV infection $^{(1)}$.

\section{Study protocol}

Data were collected during the completion of activities promoted by the Association and in the workplace as option given by the sex workers. Data were collected in the form of interview through two instruments: the first is for sociodemographic and clinical data (age, marital status, education, time of professional activity, participation in educational activities about HIV/AIDS, anti-HIV serology test and its results).

The second instrument contemplated 66 questions of an instrument concerning the knowledge about HIV/AIDS validated in Brazil $^{(12)}$ and distributed into dimensions called D3 (32 items), D4 (26 items) and D5 (08 items). D3 has questions about Modes of transmission and prevention, physiological and behavioral attributes of AIDS; D4 encompasses symptoms that HIV causes in human beings, and D5 the AIDS Treatment. The options of answers of these dimensions are: yes, no or I do not know.

In addition to these three dimensions, another one named D7 was elaborated and added to the test with questions concerning sexual practices, including 16 short-answer items (yes, no or I do not know). This dimension was added to meet the objectives of the research concerning sexual practices and assess when they were vulnerable to HIV/AIDS.

The application of the instrument had duration of 60 minutes and was performed by nurse/researcher in one moment to each volunteer. 


\section{Analysis of results and statistics}

Data collected through both instruments were inserted in an EXCEL spreadsheet and then passed along to a file in the Statistical Package for the Social Sciences (SPSS) version 19.0. Data from the first instrument were submitted to descriptive statistics with absolute and relative frequency, mean, standard deviation of the mean, maximum and minimum.

Data from the second instrument concerning dimensions D3, D4 and D5 followed the template proposed by the authors of the knowledge test that establishes scores of one (1) point for a correct answer and zero (0) for wrong answers and "I do not know."The Score Value that represents the number of correct items of each dimension was not comparable, as each dimension has a different number of items.

To convert the scores in percentage of points made, the Score was multiplied 100 times, and the result was divided by the number of items. The percentages of points were calculated by dividing the score of each dimension D3, D4 and D5 by the number of items of each dimension. To calculate the general score considering D3, D4, D5 together, the total score was added and divided by 66 , corresponding to the total number of items of the instrument used.

A cut-off point was established to classify knowledge about AIDS as limited or sufficient through the T score, being given the score below 60 points to individuals of the Low-level knowledge group and to those above 60, the High-level knowledge group. For the data of D7, a template was prepared by the authors, being assigned zero point to the answers addressing risky or unsafe sexual practice to HIV contagion and one (1) point for those with absence of risky sexual behavior.

Then the data of D7 were correlated with D3, D4 and D5 through logistic regression statistical tests to verify the relationship between the independent variables (dimensions) and dependent variable (Low- and High-knowledge level), through the measure of association odds ratio (value higher than 3.84 and $p<0.05$ ) and the Wald Test (significance value higher than 1.96).

We used the Wald Test to assess the negative B coefficient, indicating the influence inversely proportional of knowledge about dimensions (D3, D4 and D5) and risky sexual practices (D7). Standard error (SE), Degree of Freedom (DF), Significance (Sig.), Odds Ratio and 95\% confidence interval were considered for analysis. The processed data were discussed based on the theoretical framework about the HIV/AIDS epidemic.

\section{RESULTS}

The average age of all 90 female sex workers were $23.7 \pm 3.8$ years, $84.4 \%$ (76) being single, $8.9 \%$ (8) married and $6.7 \%$ (6) divorced and widowed.

Table 1 - Knowledge of female sex workers about HIV/AIDS for the dimensions (D3, D4 and D5), João Pessoa, Paraíba, Brazil, 2014 (N = 90)

\begin{tabular}{|c|c|c|c|}
\hline Dimensions/Knowledge & $\begin{array}{l}\text { Average score, standard } \\
\text { deviation, maximum and } \\
\text { minimum score }\end{array}$ & Score & $\begin{array}{c}\% \\
\text { points }\end{array}$ \\
\hline - D3: modes of transmission and prevention, physiological and behavioral attributes of AIDS. & $\begin{array}{cl}A=17,2 & S D=2,6 \\
\text { Max. }=30 & \text { Min. }=12\end{array}$ & 17.2 & 53.8 \\
\hline - D4: symptoms that HIV causes in humans. & $\begin{array}{cl}A=17,9 & S D=1,9 \\
\text { Max. }=22 & \text { Min. }=14\end{array}$ & 17.9 & 69.1 \\
\hline - D5: AIDS Treatment. & $\begin{array}{cc}A=5,6 & S D=1,0 \\
\text { Max.=8 } & \text { Min. }=3\end{array}$ & 5.6 & 70.8 \\
\hline - D3, D4 and D5 & $\begin{array}{cl}A=40,7 & S D=3,1 \\
\text { Max.=49 } & \text { Mín.=33 }\end{array}$ & 40.7 & 61.7 \\
\hline
\end{tabular}

Table 2 - Sexual practices carried out by female sex workers, João Pessoa, Paraíba, Brazil, 2014 (N = 90)

\begin{tabular}{|c|c|c|c|c|c|c|c|c|}
\hline \multirow{2}{*}{ ITEMS } & \multicolumn{2}{|c|}{ YES } & \multicolumn{2}{|c|}{ NO } & \multicolumn{2}{|c|}{ NA } & \multicolumn{2}{|c|}{ TOTAL } \\
\hline & $\mathbf{n}$ & $\%$ & $\mathbf{n}$ & $\%$ & $\mathbf{n}$ & $\%$ & $\mathbf{n}$ & $\%$ \\
\hline 1. I use condoms during sexual intercourse because I am more susceptible to catching diseases than the client. & 68 & 75.6 & 22 & 24.4 & - & - & 90 & 100.0 \\
\hline 2. I have vaginal sex without a condom for a satisfactory amount of money paid by the client. & 65 & 72.2 & 25 & 27.8 & - & - & 90 & 100.0 \\
\hline $\begin{array}{l}\text { 3. I have vaginal sex without a condom for a satisfactory amount of money paid by the client as long as he } \\
\text { agrees to withdraw his penis before ejaculation. }\end{array}$ & 64 & 71.1 & 26 & 28.9 & - & - & 90 & 100.0 \\
\hline 4. I have oral sex without a condom. & 67 & 74.4 & 23 & 25.6 & - & - & 90 & 100.0 \\
\hline 5. I have oral sex without a condom as long as the client agrees not to ejaculate inside my mouth. & 65 & 72.2 & 25 & 27.8 & - & - & 90 & 100.0 \\
\hline 6. I allow the client to perform oral sex on me. & 40 & 44.4 & 50 & 55.6 & - & - & 90 & 100.0 \\
\hline 7. I have anal sex without a condom. & 38 & 42.2 & 52 & 57.8 & - & - & 90 & 100.0 \\
\hline 8. I have anal sex without a condom as long as the client agrees to withdraw his penis before ejaculation. & 13 & 14.4 & 77 & 85.6 & - & - & 90 & 100.0 \\
\hline 9. I use a condom with the client who is initiating sexual activity. & 41 & 45.6 & 49 & 54.4 & - & - & 90 & 100.0 \\
\hline 10. I have sexual intercourse knowing that the client has HIV. & 59 & 65.6 & 30 & 33.3 & 1 & 1.1 & 90 & 100.0 \\
\hline 11. I have sex during the menstrual period. & 48 & 53.3 & 42 & 46.7 & - & - & 90 & 100.0 \\
\hline 12. I have sex with clients who do injectable drugs. & 56 & 62.2 & 34 & 37.8 & - & - & 90 & 100.0 \\
\hline 13. I have sex with a female condom. & 24 & 26.7 & 66 & 73.3 & - & - & 90 & 100.0 \\
\hline 14. I have condoms available to use with the client. & 64 & 71.1 & 26 & 28.9 & - & - & 90 & 100.0 \\
\hline 15. I have sex with a condom when the client has lesions on his penis or anus. & 68 & 75.6 & 22 & 24.4 & - & - & 90 & 100.0 \\
\hline 16. There should be no fear of contracting AIDS in the profession. & 9 & 10 & 81 & 90.0 & - & - & 90 & 100.0 \\
\hline
\end{tabular}


Table 3 - Knowledge about HIV/AIDS and its influence on the sexual practices of female sex workers through the logistic regression model with dependent variable of Low- and High-level knowledge, João Pessoa, Paraíba, Brazil, 2014 ( $N=90)$

\begin{tabular}{|c|c|c|c|c|c|c|c|c|}
\hline Independent variables (dimensions) & B & SE & *Wald & DF & Sig & *Odds & \multicolumn{2}{|c|}{$\begin{array}{c}\text { Cl Odds } \\
(95 \%)\end{array}$} \\
\hline - D3: modes of transmission and prevention, physiological and behavioral attributes of AIDS. & 0.89 & 0.33 & 7.28 & 1 & $0.007^{* *}$ & 2.43 & 1.27 & 4.65 \\
\hline - D4: symptoms that HIV causes in humans. & 1.83 & 0.55 & 10.92 & 1 & $0.001^{* *}$ & 6.27 & 2.11 & 18.65 \\
\hline - D5: AIDS Treatment. & 3.10 & 1.14 & 7.29 & 1 & $0.007^{* *}$ & 22.23 & 2.34 & 211.06 \\
\hline - D7: sexual practices of female sex workers & -0.19 & 0.20 & 0.88 & 1 & 0.346 & 0.82 & 0.54 & 1.23 \\
\hline - Constant & -72.39 & 22.07 & 10.75 & 1 & $0.001^{* *}$ & 0.000 & & \\
\hline
\end{tabular}

Note: *Significant Wald Test $>1.96$. Significant odds ratio $>3.84$ and $p<0.05 . S E=$ Standard error. $C I=$ confidence interval.

As for education, $17.8 \%$ (16) were illiterate and $62.2 \%$ (56) had a level of education equal to or higher than high school. These women worked for a maximum period of time of 15 years and a minimum of one month ( \pm 4.0 years), $70 \%$ (63) attended educational activities for HIV/AIDS prevention, $87.8 \%$ (79) of workers took the serological test for HIV with a negative result.

As for the knowledge about HIV, sex workers got a total of $61.7 \%$ answers right in the three dimensions (D3, D4 and D5) that make up the test, especially D5, about AIDS treatment (70.8\%) (Table 1).

As for the sexual practices (D7) conducted by female sex workers, those that stand out the most include sexual intercourse without a condom in exchange for a larger amount of money paid by the client (72.2\%); vaginal sex without a condom for a larger amount of money paid by the client, as long as he agrees to withdraw his penis before ejaculation (71.1\%); no condom use with the client who is initiating his sexual activity (54.4\%) and sex with a condom when the client has lesions on his penis or anus (75.6\%), and non-use of female condom (73.3\%) (Table 2).

By analyzing the data, we verify that the knowledge of sex workers about HIV shows no statistical significant contribution $(p>0.05)$ to their sexual practices, although it shows a negative B coefficient (-0.19) (Table 3).

\section{DISCUSSION}

Female sex workers know about HIV (61.7\%) and the dimensions (D3, D4, D5); however, they showed a higher level of knowledge (70.8\%) about the AIDS treatment (D5), which can be justified by scientific advances in responses to the use of Antiretroviral Therapy in the context of the HIV/AIDS epidemic, supporting it as a chronic disease $\mathrm{e}^{(13)}$.

The goal 90-90-90, proposed by UNAIDS, aims to provide HIV treatment for all who need, being set that until 2020, 90\% of all people undergoing anti-retroviral therapy must be virally suppressed. Furthermore, other goals include the elimination of vertical transmission, condom distribution programs, antiretroviral pre-exposure prophylaxis, voluntary medical male circumcision in priority countries, harm reduction services for people who inject drugs, prevention programs intended for key populations ${ }^{(14)}$.

The lowest percentage of points made (53.8\%) by sex workers was on the dimension that includes the modes of transmission and prevention, physiological and behavioral attributes of AIDS (D3). This is an alert considering that 70\% (63) of the participants received information on the prevention of sexually transmitted Infections and HIV/AIDS through educational activities carried out by the Association.
Study reveals that female sex workers who lacked knowledge about HIV prevention were more likely to have a positive HIV test result. It is important that HIV prevention programs are redrawn in a wide way in order to transmit the knowledge of HIV risk practices ${ }^{(15)}$.

A systematic review on social network and risk behavior for HIV in female sex workers showed positive evidence on the association of social support with condom use among sex workers, as it facilitates the dissemination of information, behavior, transmission of diseases ${ }^{(16)}$. Thus, the prejudiced barriers, socially imposed to this group, need to be eliminated in health services.

Sexual practices evidenced by sex workers, such as sex without a condom for a larger amount of money $(72.2 \%)$, sex during the menstrual period (53.3\%) and non-use of condom with the client who is starting his sexual activity (54.4\%) may be associated with the fact of being the only means of income for their survival ${ }^{(17)}$. These data are of great relevance for the public policy to trace specific health strategies for this population.

Study on female sex workers showed that $52.5 \%$ had had risky sexual intercourse in the last three years, being stated that the fear of the past and of sexual abuse directly reflects on accepting unprotected sex ${ }^{(18)}$.

Resistance to condom use is also a reality of female sex workers in Zhejiang/China, who reveal the inconsistent use of condoms favored by the lack of power in decision making and in negotiating safer sex. The authors of the study point out that, of the 833 female sex workers who participated in the study, $83.2 \%$ attribute the lack of condom use to the indisposition of the client ${ }^{(19)}$.

Study conducted with female sex workers in Tijuana and Ciudad Juarez, two cities that border with Mexico and the United States of America (USA), showed that the violence perpetrated by the client was related to the low rate of condom use, associated with a decrease in sexual relationship power, which hinders the negotiation about condom use ${ }^{(20)}$.

Although there is broad dissemination on ways of preventing STIs and HIV, young people still are at greater risk of acquiring STIs by not adopting safe practices, associated with the early onset of sexual intercourse. However, the authors showed a good knowledge of STIs among young people, which indicates dissociation between access to information and transformation of this knowledge into everyday practices ${ }^{(21)}$.

However, knowledge does not always guarantee adherence to safe sexual practices, as there are factors such as fear, discrimination, criminalization, loneliness, depression, which are involved in risky sexual behavior ${ }^{(15)}$. 
It should be noted that although $62.2 \%$ (56) of the women studied present level of education equal to or higher than high school, and $70.0 \%$ (63) of the participants had attended spaces for knowledge socialization about STIs and HIV prevention, data show that knowledge about HIV and education level oppose sexual practices considered unsafe by these women, as they claim having vaginal sex without a condom for a large amount of money paid by the client (72.2\%).

The fact that female sex workers have unprotected sex is related to financial needs or episodes of violence against women, besides the use of drugs by them or by their clients, which contributes to a greater vulnerability to HIV infection ${ }^{(22)}$.

The sexual practice of female sex workers with clients who have lesions on the penis and anus (75.6\%) represents risk of exposure to HIV and other STIs, because genital lesions can be a source of transmission of pathogens, without necessarily the vaginal, oral or anal penetration ${ }^{(23)}$.

Thus, $62.2 \%$ (56) of the professionals have already had sex with drug users, and this behavior exposes the individual to a higher risk of HIV infection. A study showed that men, regardless of marital status, claim to not use a condom, mainly under the influence of alcohol and other drugs ${ }^{(24)}$.

Although they have unprotected sex, the fear of contagion by HIV/AIDS was evidenced by most female sex workers (90.0\%), which may reflect the perceived susceptibility, i.e. the probability of personally experiencing the threat of HIV infection; however, fear can also motivate behavior change ${ }^{(25)}$.

Data showed that although the knowledge about HIV did not present statistical significant contribution in the sexual practices of female sex workers ( $p>0.05)$, a negative B coefficient $(-0.19)$ stood out, indicating that the smaller the number of unsafe sexual practices, the greater the knowledge about HIV/AIDS presented by these women, namely, the adoption of risky sexual practices is influenced by women's prior knowledge about HIV.

Study carried out in China (2014) with female sex workers also highlights that the effective strategy for HIV prevention would be peer education, as well as access to information on the internet with relevant articles based on the experiences of other sex workers ${ }^{(26)}$.

Female sex workers experience contextual barriers that contribute to the risk of acquiring HIV at work ${ }^{(27)}$. The lack of the women's capacity to assess the risk, by applying their knowledge during the professional activity, given the inability to negotiate condom use to accept additional money for unprotected sex with clients, as a result of the fear of economic deprivation, influences women's exposure to HIV.

\section{Study limitations}

One of the limitations of this study is the difficulty in finding and addressing sex workers in their workplaces at night times. Also, it is a cross-sectional research considering that knowledge may fluctuate over time. Thus, we recommend further studies on the knowledge of sex workers about HIV/AIDS and its influence on sexual practices, in comparison with this study.

\section{Contribution to the Nursing and public health fields}

The analysis of knowledge of sex workers about HIV/AIDS and its influence on sexual practices provides subsidies for health professionals to develop strategies and activities of health education aimed at sex workers. Regarding HIV/AIDS prevention, health professionals can use all their practice and elaborate activities to minimize the vulnerability of sex workers to HIV, thus contributing to the control of the AIDS epidemic, which is a major public health problem.

\section{CONCLUSION}

The influence of knowledge about HIV/AIDS on the sexual practices of female sex workers was not statistically significant, but risky sexual practices and insufficient knowledge about prevention, physiological and behavioral attributes were observed.

Women have a greater knowledge about AIDS treatment, which is an alert to broader and more complex issues that involve the experience in the professional activity. The participation of these women in educational activities about HIV are not sufficient to ensure adherence to safe sex practices as they involve financial aspects in the relationship with the client and do not prevent an agreement for sexual intercourse, as well as when the client has lesions on the penis or anus.

Thus, even if sex is a source of income for women, the recognition of risks and benefits of unprotected sex should be better evaluated by the sex worker.

Decision-making regarding the reformulation of public health policies and the activities carried out by health professionals is suggested, in order to consider variables intrinsic to female sex workers that may influence the prevalence and control of HIV/AIDS. It is necessary to pay attention to the educational activities of virus prevention, given that current practices have not been enough to combat the epidemic.

Further studies are necessary, since the adoption of safe sexual practices by sex workers not only involves knowledge about the theme, but also cultural, environmental, social and financial factors of the context in which they are inserted.

\section{REFERENCES}

1. Ministério da Saúde (BR). Secretaria de Vigilância em Saúde. Departamento de DST, Aids e Hepatites Virais. Boletim Epidemiológico HIV/ Aids. Brasília (DF); 2016.

2. Szwarcwald CL. Taxas de prevalência de HIV e sífilis e conhecimento, atitudes e práticas de risco relacionadas às infecções sexualmente transmissíveis nos grupos das mulheres profissionais do sexo, no Brasil: relatório técnico entregue ao Departamento de DST, Aids e Hepatites Virais; 2009. 
Knowledge of sex workers about HIV/AIDS and its influence on sexual practices Patrício ACFA, Bezerra VP, Nogueira JA, Moreira MASP, Camargo BV, Santos JS.

3. Kakchapati S, Singh DR, Rawal BB, Lim A. Sexual risk behaviors, HIV, and syphilis among female sex workers in Nepal. HIV/AIDS - Res Palliat Care. 2017;9(9):9-18. doi: 10.2147/HIV.S123928

4. Virupax R, Sanjeev SG, Sowmya R, Amrita B. Addressing vulnerabilities of female sex workers in an HIV prevention intervention in Mumbai and Thane: experiences from the Aastha project. HIV/AIDS - Res Palliat Care [Internet]. 2014[cited 2017 Feb 17];6(1):9-18. Available from: https://www.ncbi.nlm.nih.gov/pmc/articles/PMC3933664/pdf/hiv-6-009.pdf

5. Matos MA, Caetano KAA, França DDS, Pinheiro RS, Moraes LC, Teles A. Vulnerabilidade às Doenças Sexualmente Transmissíveis em mulheres que comercializam sexo em rota de prostituição e turismo sexual na Região Central do Brasil. Rev Latino-Am Enfermagem [Internet]. 2013[cited 2017 Feb 20];21(4):[7 telas]. Available from: http://www.scielo.br/pdf/rlae/v21n4/pt_0104-1169-rlae-21-04-0906.pdf

6. Goldenberg SM, Brouwer KC, Jimenez TR, Miranda SM, Mindt MR. Enhancing the ethical conduct of HIV research with migrant sex workers: human rights, policy, and social contextual influences. PLoS ONE [Internet]. 2016[cited 2017 Feb 20];11(5):e0155048. Available from: https:// journals.plos.org/plosone/article?id=10.1371/journal.pone.0155048

7. Januraga PP, Mooney-Somers J, Ward PR. Newcomers in a hazardous environment: a qualitative inquiry into sex worker vulnerability to HIV in Bali, Indonesia. BMC Public Health. 2014;14(832):1-12. doi: 10.1186/1471-2458-14-832

8. Reed EJT, Erausquin AKG, Biradavolu MSM, Blankenship KM. Client-perpetrated and husband perpetrated violence among female sex workers in Andhra Pradesh, India: HIV/STI risk across personal and work context. Sex Transm Infect. 2016;92:424-9. doi: 10.1136/ sextrans-2015-052162

9. Suryawanshi D, Sharma V, Saggurti N, Bharat S. Factors associated with the likelihood of further movement among mobile female sex workers in India: a multinomial logit approach. J Biosoc Sci. 2016;48:539-56. doi: 10.1017/S0021932015000267

10. Ramanathan S, Nagarajan K, Ramakrishnan L, Mainkar MK, Goswami P, Yadav D, et al. Inconsistent condom use by male clients during anal intercourse with occasional and regular female sex workers (FSWs): survey findings from southern states of India. BMJ Open[Internet]. 2014[cited 2018 Jun 15];4(11). Available from: https://www.ncbi.nlm.nih.gov/pubmed/25410604

11. Gezie LD, Taye BW, Ayele ATA. Time to unsafe sexual practice among cross-border female sex workers in Metemma Yohannes, North West Ethiopia. BMC Public Health. 2015;15:710. doi: 10.1186/s12889-015-2035-4

12. Natividade JC, Camargo BV. Elaboração e evidências de validade de um teste de conhecimento científico sobre HIV/aids. Rev Psicol Saúde.2012;4(1):39-52. doi: 10.20435/pssa.v4i1.123

13. Nunes Jr SS, Ciosak SI. Terapia antirretroviral para HIV/AIDS: o estado da arte. Rev Enferm UFPE [Internet]. 2018[cited 2018 Apr 10];12(4):1103-11. Available from: https://periodicos.ufpe.br/revistas/revistaenfermagem/article/viewFile/231267/28690

14. Unaids. 90-90-90: uma meta ambiciosa de tratamento para contribuir para o fim da epidemia da aids. Brasília (DF): UNAIDS; 2015.

15. Shokoohi M, Karamouzian M, Khajekazemi R, Osooli M, Sharifi H, Haghdoost AA, et al. Correlates of HIV testing among female sex workers in Iran: findings of a national bio behaviour al surveillance survey. PLoS ONE. 2016;(1):e 0147587. doi: 10.1371/journal.pone.0147587

16. Shushtari ZJ, Hosseini SA, Sajjadi H, Salimi Y, Latkin C, Snijders TAB. Social network and HIV risk behaviors in female sex workers: a systematic review. BMC Public Health. 2018;18:1.020. doi: https://doi.org/10.1186/s12889-018-5944-1

17. Leal CBM, Souza DA, Rios MA. Aspectos de vida e saúde das profissionais do sexo. Rev Enferm UFPE. 2017;11(11):4483-91. doi: https://doi. org/10.5205/1981-8963-v11i11

18. Markosyan K, Lang DL, Ralph J. Di Clemente. Correlates of inconsistent refusal of unprotected sex among Armenian female sex workers. AIDS Res Treat. 2014;7. doi: http://dx.doi.org/10.1155/2014/314145

19. Ma Q, Jiang J, Pan X, Cai G, Wang H, Zhou X et al. Consistent condom use and its correlates among female sex workers at hair salons: a crosssectional study in Zhejiang province, China. BMC Public Health. 2017;28(17):910. doi: https://doi.org/10.1186/s12889-017-4891-6

20. Conners EE, Silverman JG, Ulibarri M, Magis-Rodrigues C, Strathdee SA, Staines-Orozco H et al. Structural determinants of client perpetrated violence among female sex worker in two Mexico-U.S. AIDS Behav [Internet]. 2016[cited 2018 Aug 20];20(1):215-24. Available from: https:// www.ncbi.nlm.nih.gov/pubmed/26111732

21. Carvalho GRO, Pinto RG, Santos MS. Conhecimento sobre as infecções sexualmente transmissíveis por estudantes adolescentes de escolas públicas. Adolesc Saude [Internet]. 2018[cited 2018 Jan 10];15(1):7-17. Available from: http://www.adolescenciaesaude.com/detalhe_artigo. asp?id=703

22. Jain JP, Bristow CC, Pines HÁ, Vera AH, Rangel G, Staines $H$ et al. Factors in the HIV risk environment associated with bacterial vaginosis among HIV-negative female sex workers who inject drugs in the Mexico-United States border region. BMC Public Health. 2018;18:1032. doi: 10.1186/s12889-018-5965-9

23. Brawner BM, Sommers MS, Moore K, Aka JR, Zink T, Brown KM et al. Exploring genitoanal injury and HIV risk among women: menstrual phase, hormonal birth control, and injury frequency and prevalence. J Acquir Immune Defic Syndr. 2016;71(2):207-12. doi: 10.1097/ QAI.0000000000000824

24. Nogueira FJS, Saraiva AKM, Ribeiro MS, Freitas NM, Callou CR Filho, Mesquita CAM. Prevention, risk and desire: study on non-use of condoms. Rev Bras Promoç Saúde [Internet]. 2018[cited 2018 Feb 20];31(1):1-8. Available from: http://periodicos.unifor.br/RBPS/article/ view/6224/pdf

25. Prakash R, Manthri S, Tayyaba S, Joy A, Saksena Rs, Singh D et al. Effect of physical violence on sexually transmitted infections and treatment seeking behaviour among female sex workers in Thane District, Maharashtra, India. PLoS ONE [Internet]. 2016[cited 2017 Dec 
19];11(3):e0150347. Available from: https://journals.plos.org/plosone/article?id=10.1371/journal.pone.0150347

26. Zhang Y, Brown JD, Muessig KE, Feng X, He W. Sexual health knowledge and health practices of female sex workers in Liuzhou, China, differ by size of venue. AIDS Behav. 2014;18(2):162-70. doi: 10.1007/s10461-013-0474-4

27. Martins TA, Kerr L, Macena RHM, Mota RS, Dourado I, Brito AM, et al. Incentivos e barreiras ao teste de HIV entre mulheres profissionais do sexo no Ceará. Rev Saude Publica [Internet]. 2018[cited 2018 Feb 5];52(64):1-8. Available from: http://www.scielo.br/pdf/rsp/v52/pt_00348910-rsp-S1518-87872018052000300.pdf 